\title{
Public Awareness on Prevention Behavior of Coronavirus Disease-19 at North Sulawesi Indonesia
}

\author{
Ardiansa A. T. Tucunan ${ }^{1 *}$, Adisti A. Rumayar ${ }^{1}$, Budi T. Ratag ${ }^{1}$, Brigitte Inez Maitimo ${ }^{2}$ \\ ${ }^{1}$ Department of Public Health, Faculty of Public Health, Sam Ratulangi University, Manado, Indonesia; ${ }^{2}$ Department of Public \\ Health, National Family Planning Coordinating Board, Manado, Indonesia
}

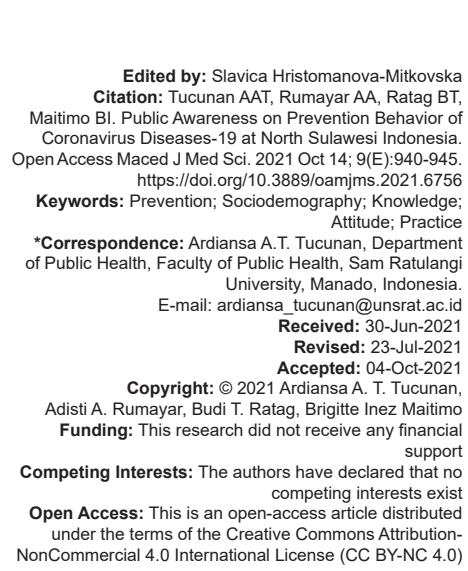

\section{Introduction}

The coronavirus diseases (COVID)-19 pandemic is a major threat to global public health and human social order. The $1^{\text {st }}$ time the COVID-19 outbreak was reported in Wuhan, the capital of Hubei Province in December 2019 [1]. The first case of the Severe acute respiratory syndrome coronavirus -2 virus in Indonesia were reported came from two Indonesian citizens who had been lived in Depok. Both of these people have a history of interacting with Japanese citizens who have already suffered from this disease (Indonesia Information Portal, Indonesia. go.id). COVID-19 has caused a great psychological impact on the public. Extraordinary situations such as disease outbreaks and epidemics can induce fear among many people [2]. Every country should urgently take all necessary measures to slow further spread and prevent its health systems from being overwhelmed by seriously ill patients with COVID-19 [3]. The outbreak of the COVID-19 pandemic made governments around the world to coerce their citizens to comply with preventive health behaviors [4].

In one study, significant change was reported in the hygiene behavior of washing hands and maintaining distance. On the other hand, significant lack of protective masks and gloves, as well as disinfectants, can be attributed to the lack of appropriate measures, as well as the lack of adequate protective equipment for their use [3]. The pandemic has led to a massive global public health campaign to slow the spread of the virus by increasing hand washing, reducing face touching, wearing masks in public and physical distancing [5]. People's behavior is influenced by social norms: What they perceive that others are doing or what they think that others approve or disapprove of Cialdini and Goldstein, (2004) [6]. Although people are influenced by norms, their perceptions are often inaccurate [7]. For example, people can underestimate health-promoting behaviors, for example, hand washing [8], and overestimate 
unhealthy behaviors [9]. Understanding individuals' behavior and their relationship to their perceived risk are important in terms of effective control of an outbreak of infectious diseases [10]. A study showed the importance of knowledge, preparation, perception of risks, and preventive measures as important thing in responding effectively to the COVID-19 outbreak. Characteristics such as gender, level of education, and age are predictive variables for better preparation for a pandemic disaster [3]. The conducted analysis showed that although most people are aware of the risks posed by the pandemic, they are particularly ignorant of the personal risks of being transmitted to others. The faster the public's perceptions change will have a meaningful effect in reducing disease transmission [11]. Perception of prevention benefit could be increased by managing communication strategies to multiple groups, emphasizing how different people can pursue effective preventive behavior [12].

This study aims to analyze the sociodemographic relationship of knowledge, attitudes, and practices of preventing COVID-19.

\section{Materials and Methods}

This study was an analytic survey with a crosssectional study design, conducted for 3 months. Data collection was carried out by sharing questionnaires through Google form and also interviewing respondents face-to-face using COVID-19 health protocols. The number of respondents involved in this study was 356 people spared across four districts and cities in North Sulawesi Province. Respondents were asked to fill informed consent before being interviewed. The technique of sample obtaining that is quota sampling, looks for all respondents who meet the inclusion criteria to become respondents until they meet the wanted minimum sample limit.

The variables included in this study are characteristics of the respondents including age, gender, occupation, income, as well as variables of knowledge, attitudes, and actions in preventing COVID-19. The variables of knowledge, attitude, and action were divided into three categories, those are no good, good enough, and good. The research instrument is a questionnaire that has gone through a process of validity and reliability testing with reference to the guidelines for the prevention and control of the coronavirus (COVID-19) Indonesian Ministry of Health, totaling 17 question items for knowledge variables, 17 question items for attitude variables, and 17 question items for action variables. Data analysis used the Chi-square test with a probability value (95\%), the value of $\alpha=0.05$.

\section{Results}

According to the result of sociodemographic respondents, most of respondent included in this study are female $(59.3 \%)$, aged $17-35$ years $(55.3 \%)$, and most of them are housewives and other occupational without mentioned it (Table 1). Most of respondents also have obtained income already as minimum government salary determined as regularly. Sociodemographic is a part of persons' characteristic which have influenced an effort to conduct actions related to human behavior. Male and female are different in conducting anything. Individuals with their own characteristic are part of current and ongoing problems to solve. Sociodemographic influences the public's desire to maintain their healthy behavior in dealing with the current COVID-19 pandemic.

Table 1: Sociodemographic of respondents

\begin{tabular}{lll}
\hline Sociodemographic & $\mathrm{n}$ & $\%$ \\
\hline Gender & & \\
Male & 145 & 40.7 \\
Female & 211 & 59.3 \\
Age (years) & 197 & \\
17-35 & 144 & 55.3 \\
$36-58$ & 15 & 40.4 \\
$>58$ & & 4.2 \\
Education & 3 & \\
Unschooled & 36 & 0.3 \\
Elementary school & 81 & 10.1 \\
Junior high school & 158 & 22.8 \\
Senior high school & 78 & 44.4 \\
College & & 21.9 \\
Occupational & 85 & \\
Housewives & 41 & 23.9 \\
Civil servant/Army/Police & 54 & 11.5 \\
Private sector & 5 & 15.2 \\
Retired & 50 & 1.4 \\
Farmer/laborer/fisherman & 121 & 14 \\
Etc & & 34 \\
Income per monthly (Rp) in million & 142 & 39.9 \\
$\leq 1$ & 170 & 47.8 \\
$2-3$ & 28 & 7.9 \\
4-5 & 16 & 4.5 \\
$>5$ & &
\end{tabular}

In this study, behavior is divided into three categories; those are knowledge, attitudes and actions. The result showed that the knowledge of most of the public about COVID-19 prevention behavior (88.8\%) was good enough; likewise, most of them showed a good attitude (73.3\%); while the action showed good enough $(54.2 \%)$. It means that most of people in north Sulawesi have a good behavior facing the situation of global pandemic of COVID-19. It became a good capital to decrease the morbidity rate of COVID-19 in North Sulawesi, when the cases became increasingly as whole cases in Indonesia (Table 2).

Table 2: Behavior of prevention of COVID-19

\begin{tabular}{lll}
\hline Behavior & $\mathrm{n}$ & $\%$ \\
\hline $\begin{array}{l}\text { Knowledge } \\
\text { Good } \\
\text { enough }\end{array}$ & 40 & 11.2 \\
$\begin{array}{l}\text { Good } \\
\text { Attitude }\end{array}$ & 316 & 88.8 \\
$\quad \begin{array}{l}\text { Negative } \\
\text { Neutral }\end{array}$ & 1 & 0.3 \\
$\quad \begin{array}{l}\text { Good } \\
\text { Action }\end{array}$ & 94 & 26.4 \\
$\quad \begin{array}{l}\text { Good } \\
\text { enough }\end{array}$ & 261 & 73.3 \\
Good & 193 & 54.2 \\
\hline COVID: Coronavirus diseases. & 163 & 45.8 \\
\hline
\end{tabular}


Table 3 shows the relationship between sociodemographic and public knowledge about the prevention of COVID-19. The results showed that both of men $(40.7 \%)$ and women $(59.3 \%)$ had good knowledge about COVID-19 prevention. This study involved most of the people of productive age and had good knowledge; these are $17-35$ years $(55.3 \%)$ and $36-58$ years $(40.4 \%)$. There is no significant difference in knowledge between people education levels because most of those involved in the research have good knowledge. Likewise, people with different occupational have good knowledge about COVID-19 prevention. This means that whatever the work of the community, they all have good knowledge. The income per monthly of the people also does not have much effect on differences in people's knowledge, because most people with different incomes have good knowledge. Statistical analysis with Chi-square test showed the different results of relationship between each variable of demography and knowledge. There is a significant relationship between gender and knowledge with $p=0.002$; but most of variables are no relationship with each $p$ values; age and knowledge (0.4); educational and knowledge (0.0.85); occupational and knowledge (0.239); and income per monthly (0.761).

Table 3: Relationship between sociodemographic and knowledge of COVID-19 prevention

\begin{tabular}{|c|c|c|c|c|c|}
\hline \multirow[t]{2}{*}{ Variables } & \multicolumn{3}{|c|}{$\begin{array}{l}\text { Knowledge of COVID-19 } \\
\text { prevention }(\%)\end{array}$} & \multirow[t]{2}{*}{ Total } & \multirow[t]{2}{*}{$\mathrm{p}$-value } \\
\hline & No good & Good enough & Good & & \\
\hline \multicolumn{6}{|l|}{ Gender } \\
\hline Male & $0(0)$ & $26(7.3)$ & $119(33.4)$ & $145(40.7)$ & \multirow[t]{2}{*}{0.002} \\
\hline Female & $0(0)$ & $14(3.9)$ & $197(55.3)$ & 211 (59.3) & \\
\hline \multicolumn{6}{|l|}{ Age (years) } \\
\hline $17-35$ & $0(0)$ & $22(6.2)$ & $175(49.2)$ & $197(55.3)$ & \multirow[t]{3}{*}{0.4} \\
\hline $36-58$ & $0(0)$ & $17(4.8)$ & $127(3.6)$ & $144(40.4)$ & \\
\hline$>58$ & $0(0)$ & $0(0)$ & $14(3.9)$ & $14(3.9)$ & \\
\hline \multicolumn{6}{|l|}{ Education } \\
\hline Unschooled & $0(0)$ & $0(0)$ & $3(0.8)$ & $3(0.8)$ & \multirow[t]{5}{*}{0.085} \\
\hline Elementary school & $0(0)$ & $11(3.1)$ & $25(7.0)$ & $36(10.1)$ & \\
\hline Junior high school & $0(0)$ & $3(0.8)$ & 78 (21.9) & $81(22.8)$ & \\
\hline Senior high school & $0(0)$ & $19(5.3)$ & $139(39.0)$ & $158(44.4)$ & \\
\hline College & $0(0)$ & $7(1.9)$ & $71(19.9)$ & $78(21.9)$ & \\
\hline \multicolumn{6}{|l|}{ Occupational } \\
\hline Housewives & $0(0)$ & $8(2.2)$ & 77 (21.6) & 85 (23.9) & \multirow[t]{2}{*}{0.239} \\
\hline Civil servant/Army/ & $0(0)$ & $3(0.8)$ & $38(10.7)$ & 41 (11.5) & \\
\hline \multicolumn{6}{|l|}{ Police } \\
\hline Private sector & $0(0)$ & $3(0.8)$ & $51(14.3)$ & \multicolumn{2}{|l|}{$54(15.2)$} \\
\hline Retired & $0(0)$ & $0(0)$ & $5(1.4)$ & \multicolumn{2}{|l|}{$5(1.4)$} \\
\hline $\begin{array}{l}\text { Farmer/laborer/ } \\
\text { fisherman }\end{array}$ & $0(0)$ & $10(2.8)$ & $40(11.2)$ & \multicolumn{2}{|l|}{$50(14.0)$} \\
\hline Etc & $0(0)$ & $16(4.5)$ & $103(28.9)$ & $119(33.4)$ & \\
\hline \multicolumn{6}{|c|}{ Income per monthly (Rp) } \\
\hline$\leq 1$ million & $0(0)$ & $18(5.1)$ & $124(34.8)$ & $142(39.9)$ & \multirow[t]{4}{*}{0.761} \\
\hline 2-3 million & $0(0)$ & $19(5.3)$ & $151(42.4)$ & $170(47.8)$ & \\
\hline 4-5 million & $0(0)$ & $2(0.1)$ & $26(7.3)$ & $28(7.9)$ & \\
\hline$>5$ million & $0(0)$ & $1(0.3)$ & $15(4.2)$ & $16(4.5)$ & \\
\hline
\end{tabular}

In searching for the relationship between sociodemographic variables including gender, age, education, occupational, income per month with people's attitudes toward COVID-19 prevention; it was found that men had good attitudes (27.2\%) and quite good $(13.2 \%)$ toward the prevention of COVID-19; while women are bigger than men with good attitude (46.1\%) and quite good attitude (13.2\%). At the productive age, namely, 17-58 years, people have good attitudes and are good enough to be directly proportional to the knowledge they have, with the respective percentages aged $17-35$ years $(41.3 \%$ and $13.8 \%)$, and aged $36-58$ years $(28.4 \%$ and $12.1 \%)$. Most people with different levels of education have good attitudes toward the prevention of COVID-19, respectively, senior high school (31.5\%), junior high school (18.3\%), college $(17.4 \%)$, elementary school $(5.6 \%)$, and unschooled $(0.6 \%)$.

Different occupations do not make a difference in attitudes among people because on average they have good attitudes toward COVID-19 prevention. Likewise with income per month, although income per month is different, the public attitude toward preventing COVID-19 is still good. Statistically, only gender has a relationship toward people's attitudes toward COVID-19 prevention with $p=0.046$; while most of the variables, namely, age (0.333), education (0.085), occupation $(0.152)$, and income (0.966), did not have a significant relationship with attitudes toward the prevention of COVID-19 (Table 4).

Basically, the percentage of sociodemographic variables toward COVID-19 prevention measures is almost same as the percentages in both knowledge and attitude variables which have produced good actions in preventing COVID-19. There was no significant difference regarding the univariate results for each of the sociodemographic variables. But with statistical tests seeking the relationship of each variable with preventive measures, most of the variables had a significant relationship with prevention measures, including age (0.008), education (0.009), and occupation (0.038); and only the gender variable (0.895) and monthly income (0.077) had no statistical relationship (Table 5).

\section{Discussion}

COVID-19 prevention behavior can be viewed from three aspects that are related to one another, namely knowledge, attitudes, and actions. These three variables must be related to one another, meaning that if knowledge is good, attitudes and actions should also to be good. This study showed the truth of the above assumptions, with the respective percentages of knowledge, attitudes, and actions showing good and good enough. The public in North Sulawesi understood enough about how to prevent COVID-19 with the right behavior.

Through using a cross tabulation to see the relationship between sociodemographic factors and each variable (knowledge, attitudes, and actions) of the prevention behavioral of COVID-19, it was found that only the gender variable $(p=0.002)$ has relationship toward knowledge; while age (0.400), education (0.085), occupation (0.239), and monthly income (0.761) had no relationship at all with people's knowledge. The results also showed that only the gender variable 
(0.046) had a statistically significant relationship to the attitude of COVID-19 prevention; while age (0.333), education (0.085), occupation (0.152), and monthly income (0.966) had no relationship with the attitude of preventing COVID-19. A quite different result was shown by the relationship between sociodemographic variables and preventive measures, where age (0.008), education (0.009), and occupation (0.038) had significant relationship statistically, while gender (0.895) and monthly income (0.077) did not has a significant relationship toward COVID-19 prevention measures. Most of the sociodemographic variables reacted more to the variable of COVID-19 preventive action than the variables of knowledge and attitude. The result of study showed that male respondents, under 25 years, with the lower education and working in the government, tended to support lifting the lockdown as soon as possible [1].

With good preventive behavior, including public education, strengthening individual protection, media isolation and controlling population mobility, and reducing human gathering will be a determining factor in stopping the spread of the COVID-19 virus [13]. Sociodemographic variables are very important to study in different groups to understand people's anxiety during a pandemic. Without knowing this, it will be difficult to know whether education and COVID-19 prevention programs are needed or not, and if it is needed which groups to target and were. This COVID-19 prevention behavior, such as washing hands, social distancing, individual hygiene, and others, is related to fear and health-related behavior, and this is complex [2]. Research related to demographic groups has also shown to respond well to programs launched by the government to control new infections such as COVID-19. Demographic characteristics can predispose an individual to be infected by the disease, so a measure can be taken to minimize COVID-19 infection [14].

The results of study is supported research by Yanti et al. (2020), where the majority of respondents had good knowledge of preventing the transmission of COVID-19, especially with social distancing [15]. However, only more than half of respondents have a good attitude toward preventing the transmission of COVID-19; and most respondents have good behavior toward preventing the spread of COVID-19 through social distancing. Arora and Grey (2020) concluded that it is fundamental to produce a better understanding of the likely behavioral alterations in the general population and their impact upon psychological and mental health [16]. Public health policies, measures, and media are needed to promote greater self-awareness, selfhelp, and self-care within the home setting to prevent later strains on the healthcare system. At the beginning of COVID-19, people's knowledge was well informed and ready to conform to the suggested behaviors [17]. In addition, the steps that need to be taken to overcome a pandemic must be clearly understood so that effective management can be carried out [18]. COVID-19 prevention behavior needs to be improved because this is related to the influence on the psychology and mental health of the population, especially in vulnerable groups, that is why psychological interventions need to be carried out to promote welfare and minimize mental health risks in community [19].

Table 4: Relationship between sociodemographic and attitude of COVID-19 prevention

\begin{tabular}{|c|c|c|c|c|c|}
\hline \multirow[t]{2}{*}{ Variables } & \multicolumn{3}{|c|}{ Attitude of COVID-19 prevention (\%) } & \multirow[t]{2}{*}{ Total } & \multirow[t]{2}{*}{ p-value } \\
\hline & No good & Good enough & Good & & \\
\hline \multicolumn{6}{|l|}{ Gender } \\
\hline Men & $1(0.3)$ & $47(13.2)$ & $97(27.2)$ & $145(40.7)$ & \multirow[t]{2}{*}{0.046} \\
\hline Women & $0(0)$ & 47 (13.2) & $164(46.1)$ & $211(59.3)$ & \\
\hline \multicolumn{6}{|l|}{ Age (years) } \\
\hline $17-35$ & $1(0.3)$ & $49(13.8)$ & $147(41.3)$ & $197(55.3)$ & \multirow[t]{3}{*}{0.333} \\
\hline $36-58$ & $0(0)$ & $43(12.1)$ & $101(28.4)$ & $144(40.4)$ & \\
\hline$>58$ & $0(0)$ & $1(0.3)$ & $13(3.7)$ & $14(3.9)$ & \\
\hline \multicolumn{6}{|l|}{ Education } \\
\hline Unschooled & $0(0)$ & $1(0.3)$ & $2(0.6)$ & $3(0.84)$ & \multirow[t]{5}{*}{0.085} \\
\hline Elementary school & $0(0)$ & $16(4.5)$ & $20(5.6)$ & $36(10.1)$ & \\
\hline Junior high school & $1(0.3)$ & $15(4.2)$ & $65(18.3)$ & $81(22.8)$ & \\
\hline Senior high school & $0(0)$ & 46 (12.9) & $112(31.5)$ & $158(4.4)$ & \\
\hline College & $0(0)$ & $16(4.5)$ & $62(17.4)$ & 78 (21.9) & \\
\hline \multicolumn{6}{|l|}{ Occupational } \\
\hline Housewives & $0(0)$ & $23(6.5)$ & $62(17.4)$ & 85 (23.9) & \multirow[t]{5}{*}{0.152} \\
\hline Civil servant & $0(0)$ & $10(2.8)$ & $31(8.7)$ & 41 (11.5) & \\
\hline Private sector & $0(0)$ & $21(5.9)$ & $33(9.3)$ & $54(15.2)$ & \\
\hline Retired & $0(0)$ & $1(0.3)$ & $4(1.1)$ & $5(1.4)$ & \\
\hline $\begin{array}{l}\text { Farmer/laborer/ } \\
\text { fisherman }\end{array}$ & $1(0.3)$ & $17(4.8)$ & $32(8.9)$ & $50(14.0)$ & \\
\hline \multicolumn{6}{|l|}{ Income per monthly (Rp) } \\
\hline$\leq 1$ million & $0(0)$ & $36(10.1)$ & $106(29.8$ & $142(39.9)$ & \multirow[t]{4}{*}{0.966} \\
\hline 2-3 million & $1(0.3)$ & 47 (13.2) & $122(34.3)$ & $170(47.8)$ & \\
\hline 4-5 million & $0(0)$ & $7(1.9)$ & $21(5.9)$ & $28(7.9)$ & \\
\hline$>5$ million & $0(0)$ & $4(1.1)$ & $12(3.4)$ & $16(4.5)$ & \\
\hline
\end{tabular}

True understanding of how a person responds to a pandemic is based on personality traits, and illustrates the importance of perceptions of risk and one's own hygiene. During the pandemic, individuals' behavior could be predicted, if we know information about their personality traits, so that health-care providers can design appropriate interventions aimed at raising awareness among people in the community [20]. Public understanding of the epidemic is an important consideration for psychological interventions [21]. Through good knowledge and attitudes, behavior changes will be occurred to ensure safety, for example, by reducing physical contact, visits to health care facilities, delaying plans, and washing hands more frequently [22]. Efforts to overcome psychosocial crises and their prevention models also need to be carried out by the government, health service personnel and stakeholders [23], so that the psychosocial situation in communities did not worsen.

Public knowledge about the prevention of COVID-19 is determined by sociodemographic factors (age, education, and work) because it is a significant predictor of public awareness, so that good communication in the community is needed so that people understand the prevention of the current COVID-19 outbreak [24]. In a study, it was found that the level of public understanding of COVID-19 was positively correlated with hand washing, so it is recommended that knowledge is important to be able to motivate COVID-19 prevention behavior [25]. A person's behavior before the pandemic has a very significant relationship with post-pandemic behavior [26]. The 
daily behavior of the community before the COVID-19 outbreak occurs will greatly affect the current situation of the COVID-19 outbreak, because this behavior is basically difficult to change, especially after a long time period. Yau et al. (2020) concluded that there is a need to explore these changes with further qualitative and quantitative studies for a better understanding of the behavior changes specific to COVID-19 pandemic [27]. Furthermore, the conclusion made by Wise et al. (2020) indicated that behavior especially in social distancing and hand washing was most strongly predicts, and has implications for the public's understanding of how perceptions of risk and protective behavior can facilitate early intervention during a large-scale pandemic [11].

The implication of this research is the need for obedience from all elements of society to comply with the health protocol in an effort to prevent COVID by providing strict sanctions so that it can break the chain of the spread of COVID-19.

Table 5: Relationship between sociodemographic and behavior of COVID-19 prevention

\begin{tabular}{|c|c|c|c|c|c|}
\hline \multirow{2}{*}{ Variables } & \multicolumn{3}{|c|}{ Behavior of COVID-19 prevention (\%) } & \multirow[t]{2}{*}{ Total } & \multirow[t]{2}{*}{ p-value } \\
\hline & No good & Good enough & Good & & \\
\hline \multicolumn{6}{|l|}{ Gender } \\
\hline Male & $0(0)$ & $78(2.2)$ & $67(18.8)$ & $145(40.7)$ & 0.895 \\
\hline Female & $0(0)$ & $115(32.3)$ & 96 (26.9) & $211(59.3)$ & \\
\hline \multicolumn{6}{|l|}{ Age (years) } \\
\hline $17-35$ & $0(0)$ & $121(33.9)$ & $76(21.3)$ & $197(55.3)$ & 0.008 \\
\hline $36-58$ & $0(0)$ & $64(17.9)$ & $80(22.5)$ & $144(40.4)$ & \\
\hline$>58$ & $0(0)$ & $8(2.2)$ & $6(1.7)$ & $14(3.9)$ & \\
\hline \multicolumn{6}{|l|}{ Education } \\
\hline Unschooled & $0(0)$ & $1(0.3)$ & $2(0.6)$ & $3(0.8)$ & 0.009 \\
\hline Elementary school & $0(0)$ & $25(7.0)$ & $11(3.1)$ & $36(10.1)$ & \\
\hline Junior high school & $0(0)$ & $35(9.8)$ & 46 (12.9) & $81(22.8)$ & \\
\hline Senior high school & $0(0)$ & $80(22.5)$ & 78 (21.9) & $158(44.4)$ & \\
\hline College & $0(0)$ & $52(14.6)$ & $26(7.3)$ & $78(21.9)$ & \\
\hline \multicolumn{6}{|l|}{ Occupational } \\
\hline Housewives & $0(0)$ & $50(14.0)$ & $35(9.8)$ & $85(23.9)$ & 0.038 \\
\hline Civil servant/Police & $0(0)$ & $19(5.3)$ & $22(6.2)$ & $41(11.5)$ & \\
\hline Private sector & $0(0)$ & $25(7.0)$ & $29(8.1)$ & $54(15.2)$ & \\
\hline Retired & $0(0)$ & $2(0.6)$ & $3(0.8)$ & $5(1.4)$ & \\
\hline Farmer/laborer/fisherman & $0(0)$ & $21(5.9)$ & $29(8.1)$ & $50(14.0)$ & \\
\hline Etc & $0(0)$ & $76(21.3)$ & $45(12.6)$ & $121(33.9)$ & \\
\hline \multicolumn{6}{|l|}{ Income per monthly (Rp) } \\
\hline$\leq 1$ million & $0(0)$ & 79 (22.2) & $63(17.7)$ & $142(39.9)$ & 0.077 \\
\hline 2-3 million & $0(0)$ & $98(27.5)$ & $72(20.2)$ & $170(47.8)$ & \\
\hline 4-5 million & $0(0)$ & $11(3.1)$ & $17(4.8)$ & $28(7.9)$ & \\
\hline$>5$ million & $0(0)$ & $5(1.4)$ & $11(3.1)$ & $16(4.5)$ & \\
\hline
\end{tabular}

\section{Conclusion}

It is important for the government and society to take a role by becoming more concerned about the COVID-19 pandemic through wise steps to prevent and protect public health using all available resources. Urgent action is needed to mitigate the potentially devastating effects of COVID-19. Treatment needs to be taken by emergency management agencies to address different perceptions of the risk of the impact of COVID-19, by developing targeted strategies to improve community preparation by promoting behavior change and improving risk management decision-making.

\section{Acknowledgment}

The author would like to thank The Dean of Faculty of Public Health, Sam Ratulangi University, for giving permission and support in implementing this research data collection.

\section{References}

1. Chen X, Gao H, Zou Y, Lin F. Changes in psychological wellbeing, attitude and information-seeking behaviour among people at the epicentre of the COVID-19 pandemic: A panel survey of residents in Hubei province, China. Epidemiol Infect. 2020;148:e201. https://doi.org/10.1017/s0950268820002009 PMid:32873358

2. Pakpour AH, Griffiths MD. The fear of COVID-19 and its role in preventive behaviors. J Concurr Disord. 2020;2(1):58-63.

3. Cvetković VM, Nikolić N, Radovanović Nenadić U, Öcal A, K Noji E, Zečević M. Preparedness and preventive behaviors for a pandemic disaster caused by COVID-19 in Serbia. Int J Environ Res Public Health. 2020;17(11):4124. https://doi.org/10.3390/ ijerph17114124

PMid:32527056

4. Fischer I, Avrashi S, Oz T, Fadul R, Gutman K, Rubenstein D, et al. The behavioural challenge of the COVID-19 pandemic: Indirect measurements and personalized attitude changing treatments (IMPACT). R Soc Open Sci. 2020;7(8):201131. https://doi.org/10.1098/rsos.201131

PMid:32968537

5. Bavel JJ, Baicker K, Boggio PS, Capraro V, Cichocka A, Cikara M, et al. Using social and behavioural science to support COVID-19 pandemic response. Nat Hum Behav. 2020;4(5):460-71.

PMid:32355299

6. Cialdini RB, Goldstein NJ. Social Influence: Compliance and conformity. Annu Rev Psychol. 2004;55:591-621. https://doi. org/10.1146/annurev.psych.55.090902.142015

\section{PMid:14744228}

7. Miller DT, Prentice DA. The construction of social norms and standards. In: Social Psychology: Handbook of Basic Principles. New York: The Guilford Press; 1996. p. 799-829.

8. Dickie R, Rasmussen S, Cain R, Williams L, Mackay W. The effects of perceived social norms on handwashing behaviour in students. Psychol Health Med. 2018;23(2):154-9. https://doi. org/10.1080/13548506.2017.1338736

PMid:28592138

9. Berkowitz A. An overview of the social norms approach. In: Stewart L, Lederman LC, editors. Changing the Culture of College Drinking: A Socially Situated Health Communication Campaign. New York: Hampton Press; 2005. https://doi. org/10.1080/10810730701325822

10. Leung GM, Lam TH, Ho LM, Ho SY, Chan BH, Wong IO, et al. The impact of community psychological responses on outbreak control for severe acute respiratory syndrome in Hong Kong. J Epidemiol Community Health. 2003;57(11):857-63. https://doi. org/10.1136/jech.57.11.857 PMid:14600110

11. Wise T, Zbozinek TD, Michelini G, Hagan CC, Mobbs D. Changes in risk perception and self-reported protective behaviour during the first week of the COVID-19 pandemic in the United States. 
R Soc Open Sci. 2020;7(9):200742. https://doi.org/10.1098/ rsos.200742

PMid:33047037

12. Barakat AM, Kasemy ZA. Preventive health behaviours during Coronavirus disease 2019 pandemic based on health belief model among Egyptians. Middle East Curr Psychiatry. 2020;27(1):43. https://doi.org/10.1186/s43045-020-00051-y

13. Qiu J, Shen B, Zhao M, Wang Z, Xie B, Xu Y. A nationwide survey of psychological distress among Chinese people in the COVID-19 epidemic: Implications and policy recommendations. Gen Psychiatr. 2020;33(2):e100213. https://doi.org/10.1136/ gpsych-2020-100213 PMid:32215365

14. Long VJ, Liu JC. Behavioral Changes during the COVID-19 Pandemic: Results of a National Survey in Singapore, medRxiv; 2020.

15. Yanti B, Mulyadi E, Wahiduddin W, Novika RG, Da'at Arina YM, Martani NS, et al. Community knowledge, attitudes, and behavior towards social distancing policy as a means of preventing transmission of COVID-19 in Indonesia. J Adm Kesehatan Indones. 2020;8:4-14. https://doi.org/10.20473/jaki. v8i2.2020.4-14

16. Arora T, Grey I. Health behaviour changes during COVID-19 and the potential consequences: A minireview. J Health Psychol. 2020;25(9):1155-63. https://doi. org/10.1177/1359105320937053 PMid:32551944

17. Pagnini F, Bonanomi A, Tagliabue S, Balconi M, Bertolotti M, Confalonieri $\mathrm{E}$, et al. Knowledge, concerns, and behaviors of individuals during the first week of the Coronavirus disease 2019 pandemic in Italy. JAMA Netw Open. 2020;3(7):e2015821. https://doi.org/10.1001/jamanetworkopen.2020.15821 PMid:32706385

18. Perveen A, Hamzah H, Ramlee F, Othman A, Minhad M. Mental health and coping response among Malaysian adults during COVID-19 pandemic movement control order. J Crit Rev. 2020;7(18):653-60.

19. Holmes EA, O'Connor RC, Perry VH, Tracey I, Wessely S, Arseneault $\mathrm{L}$, et al. Multidisciplinary research priorities for the COVID-19 pandemic: A call for action for mental health science. Lancet Psychiatry. 2020;7(6):547-60. https://doi.org/10.1016/ s2215-0366(20)30168-1
PMid:32304649

20. Abdelrahman M. Personality traits, risk perception, and protective behaviors of Arab residents of Qatar during the COVID-19 pandemic. Int J Ment Health Addict. 2020;6:1-12. https://doi.org/10.1007/s11469-020-00352-7

21. Liu X, Luo WT, Li Y, Li CN, Hong ZS, Chen HL, et al. Psychological status and behavior changes of the public during the COVID-19 epidemic in China. Infect Dis Poverty. 2020;9(1):58. https://doi.org/10.1186/s40249-020-00678-3 PMid:32471513

22. Balkhi F, Nasir A, Zehra A, Riaz R. Psychological and behavioral response to the Coronavirus (COVID-19) pandemic. Cureus. 2020;12(5):e7923. https://doi.org/10.7759/cureus.7923 PMid:32499970

23. Dubey $\mathrm{S}$, Biswas $\mathrm{P}$, Ghosh R, Chatterjee S, Dubey MJ, Chatterjee S, et al. Psychosocial impact of COVID-19. Diabetes Metab Syndr. 2020;14(5):779-88. https://doi.org/10.1016/j. dsx.2020.05.035 PMid:32526627

24. Nooh HZ, Alshammary RH, Alenezy JM, Alrowaili NH, Alsharari AJ, Alenzi NM, et al. Public awareness of coronavirus in Al-Jouf region, Saudi Arabia. Z Gesundh Wiss. 2020;13:1-8. https://doi.org/10.1007/s10389-020-01209-y PMid:32206545

25. Shiina A, Niitsu T, Kobori O, Idemoto K, Hashimoto T, Sasaki T, et al. Relationship between perception and anxiety about COVID-19 infection and risk behaviors for spreading infection: A national survey in Japan. Brain Behav Immun Health. 2020;6:100101. https://doi.org/10.1016/j.bbih.2020.100101 PMid:32835297

26. Papageorge NW, Zahn MV, Belot M, van den Broek-Altenburg E, Choi S, Jamison JC, et al. Socio-demographic factors associated with self-protecting behavior during the COVID-19 pandemic. J Popul Econ. 2021;34(2):1-48. https://doi.org/10.3386/w27378 PMid:33462529

27. Yau EK, Ping NP, Shoesmith WD, James S, Hadi NM, Loo JL. The behaviour changes in response to COVID-19 pandemic within Malaysia. Malays J Med Sci. 2020;27(2):45-50. PMid:32788840 